\title{
Inheritance of coffee leaf rust resistance and identification of AFLP markers linked to the resistance gene
}

\author{
Giovani Greigh de Brito $\cdot$ Eveline Teixeira Caixeta • \\ Ana Paula Gallina • Eunize Maciel Zambolim • \\ Laércio Zambolim • Valdir Diola $\cdot$ Marcelo Elhers Loureiro
}

Received: 1 May 2009/ Accepted: 4 January 2010/Published online: 19 January 2010

(C) Springer Science+Business Media B.V. 2010

\begin{abstract}
The most important disease of Coffea arabica is coffee leaf rust caused by the fungus Hemileia vastatrix. The purpose of this study was to characterize the inheritance of coffee resistance gene(s) to race II of this pathogen and to identify and map molecular markers linked to this trait. Different populations were used: $\mathrm{F}_{2}$ (160 plants), $\mathrm{BCr}$ (20), and BCs (135), derived from a cross between the resistant genotype Híbrido de Timor UFV 427-15 and the susceptible cultivar Catuaí Amarelo UFV 2143-236 (IAC 30). The segregation analysis showed that the resistance of Híbrido de Timor to race II of the $H$. vastatrix is conferred by a single dominant gene. The amplification of 176 AFLP (Amplified fragment
\end{abstract}

G. G. de Brito ( $\square$ )

Departamento de Pesquisa desenvolvimento \& Inovação, Laboratório de Biotecnologia Vegetal, Embrapa Algodão, Campina Grande, PB 58428-095, Brazil

e-mail: giovani@cnpa.embrapa.br

E. T. Caixeta

Embrapa Café, Instituto de Biotecnologia Aplicada à Agropecuária (BIOAGRO), Universidade Federal de Viçosa, Viçosa, MG 36570-000, Brazil

A. P. Gallina · E. M. Zambolim · L. Zambolim Instituto de Biotecnologia Aplicada à Agropecuária (BIOAGRO), Universidade Federal de Viçosa, Viçosa, MG 36570-000, Brazil

V. Diola $\cdot$ M. E. Loureiro

Departamento de Biologia Vegetal, Universidade Federal de Viçosa, Viçosa, MG 36570-000, Brazil length polymorphism) primer combinations using bulked segregant analysis (BSA) allowed the identification of three molecular markers linked to the resistance gene. Genetic mapping of these three markers in the $F_{2}$ population indicated that they are distributed on both sides, flanking the resistance gene. The markers E.CTC/M.TTT405 and E.CGT/M.TGT 300 were found linked to the resistance gene at $8.69 \mathrm{cM}$ (LOD 18.91) and 25.10 cM (LOD 5.37), respectively, while E.CCT/M.TTC230 was localized on the other side of the gene, at $20.50 \mathrm{cM}$ (LOD 6.15). These markers are the first rust resistance markers identified in Híbrido de Timor and can be useful for marker assisted selection in coffee breeding programs.

Keywords Coffee leaf rust - Resistance gene · AFLP marker · Bulked segregant analysis

\section{Introduction}

Coffee leaf rust, caused by the biotrophic fungus Hemileia vastatrix Berk. et $\mathrm{Br}$., is considered the main disease in commercial Coffea arabica, but C. canephora can be also most affected. Spreading out from Africa and Asia, the disease first reached Brazil in 1970. Nowadays, it's present in all coffee producing countries, except in Hawaii and Australia.

The importance of establishing durable resistance to this pathogen lies in the fact that the economic damage 
caused by the yield reduction at the global level varies from one to two billion dollars annually, since the majority of the arabica coffee cultivar are susceptible (Van der Vossen 2001), and C. canephora can sometimes be affected as well. In Brazil, it is estimated that disease losses, in the absence of effective control measures, can amount to $30 \%$ of the production (Kushalappa and Eskes 1989; Zambolim et al. 1999). The main damages caused by the disease are premature defoliation, resulting in a reduced leaf area and withered lateral branches, leading to a gradual debilitation of the infected plant (Matiello et al. 2002). Chemical control with protective copper and/or systemic fungicides of the triazol group for this disease proved effective (Matiello et al. 2002; Zambolim et al. 2002). Although efficient, the effects on the environment and non-target organisms may lead to a population explosion of pests and or other coffee diseases. Moreover, the selection pressure exerted on the pathogen with this control strategy paves the way for the emergence of new fungus races resistant to the products applied (Zambolim et al. 2002). The most appropriate alternative to chemical control is the use of resistant cultivars, which can be obtained by conventional breeding, aided by molecular techniques (Fazuoli et al. 2002; Pereira et al. 2002; Sera et al. 2002; Fazuoli et al. 2005).

Several research groups from different regions have sought to achieve durable resistance to coffee leaf rust, resulting in initial success followed by disappointments because of the emergence of new virulent pathogen races able to infect the initially resistant plants (Van der Vossen 2001). The variability in pathogenicity of biotrophic fungi, including $H$. vastatrix, is normally great. To date, about 45 physiological races of this species have been identified (Várzea and Marques 2005). Thirteen races have been confirmed in Brazil and among these, race II with the virulence gene v5 predominates in commercial crops areas, since the main commercial cultivars planted worldwide in the different producing regions contain the factor $\mathrm{S}_{\mathrm{H}} 5$ of rust resistance (Fazuoli et al. 2005). The use of genotypes derived from the Híbrido de Timor (hybrid of the natural crossing between $C$. arabica and C. canephora) containing the resistance genes $\mathrm{S}_{\mathrm{H}} 5$, $\mathrm{S}_{\mathrm{H}} 6, \mathrm{~S}_{\mathrm{H}} 7, \mathrm{~S}_{\mathrm{H}} 8$ and $\mathrm{S}_{\mathrm{H}} 9$ (Wagner and Bettencourt 1965; Vishveshwara 1974; Bettencourt and Rodrigues 1988) is an interesting source for the use in breeding programs for coffee leaf rust resistance.
The resistance of coffee to this pathogen has been much explored in C. arabica and other species of the same genus. Components of fungus resistance, of monogenic as well as oligogenic and polygenic nature, have been identified. Within the genus Coffea, at least nine dominant genes $\left(\mathrm{S}_{\mathrm{H}} 1-\mathrm{S}_{\mathrm{H}} 9\right)$ confer resistance to $H$. vastatrix. Breeding programs for rust resistance in coffee have focused on the accessions collected in the primary centers of diversity (Bettencourt and Rodrigues 1988). Among these resistance factors present in the genus Coffea, $\mathrm{S}_{\mathrm{H}} 1, \mathrm{~S}_{\mathrm{H}} 2, \mathrm{~S}_{\mathrm{H}} 4$ and $\mathrm{S}_{\mathrm{H}} 5$ were found in $C$. arabica. Other genes, such as $\mathrm{S}_{\mathrm{H}} 6, \mathrm{~S}_{\mathrm{H}} 7, \mathrm{~S}_{\mathrm{H}} 8$ and $\mathrm{S}_{\mathrm{H}} 9$, were introgressed from C. canephora, while $\mathrm{S}_{\mathrm{H}} 3$ originated from C. liberica (Wagner and Bettencourt 1965; Vishveshwara 1974; Bettencourt and Rodrigues 1988).

It has been demonstrated that the genes present in C. arabica, alone or in combination, have not conferred durable resistance against many $H$. vastatrix races. However, the $\mathrm{S}_{\mathrm{H}} 3$ factor, present in C. liberica has conferred durable resistance to commercial crops under field conditions (Srinivasan and Narasimhaswamy 1975; Prakash et al. 2005). This information suggests that a combined accumulation of these genes in other varieties that have agronomic traits of interest could establish the desired durable resistance (Kushalappa and Eskes 1989).

Although coffee can be considered one of the most studied and well-documented plant regarding its resistance to $H$. vastatrix, development of selection strategies involving molecular markers linked to resistance remains difficult. Hence, the identification of molecular markers closely linked to $S_{H}$ genes and other conditioning genes of coffee rust resistance could be very helpful in the development of cultivars with durable resistance characteristics to this pathogen.

This paper reports three AFLP markers linked to the resistant gene in Híbrido de Timor UFV 427-15 by analyzing the $F_{2}$ population from artificial cross between this resistant parent and the susceptible genotype Catuaí Amarelo UFV 2143-236 (IAC 30).

\section{Materials and methods}

Plant material and crosses

A $F_{1}$ plant ( $\left.\mathrm{H} 421-4\right)$, derived from the cross between the resistant source Híbrido de Timor UFV 427-15 
and the susceptible variety Catuaí Amarelo UFV 2143-236 (IAC 30), was selfed to generate the $F_{2}$ seeds and used for backcrossing with Catuaí Amarelo UFV 2143-236 (BCs) and the Híbrido de Timor UFV 427-15 (BCr). The UFV $427-15$ is a rust resistant germplasm introduced from Centro de Investigação das Ferrugens do Cafeeiro (CIFC), Portugal, as a seed collected in coffee trees selected in the Estação Regional de Uige (ERU) of the Instituto de Café de Angola. The resultants $160 \mathrm{~F}_{2}, 135 \mathrm{BCs}$ and $20 \mathrm{BCr}$ plants were used to characterize the genetic resistance. To identify markers linked to the resistance gene, only the $F_{2}$ plants were used. All crosses were performed in Universidade Federal de Viçosa experimental station at Viçosa, Minas Gerais State, Brazil.

\section{Disease evaluation}

The resistance was characterized by inoculation of the abaxial leaves of parental genotypes (resistant and susceptible) and $\mathrm{F}_{1}, \mathrm{~F}_{2}, \mathrm{BCs}$ and $\mathrm{BCr}$ plants, with 20 drops $(5.0 \mu \mathrm{l}$ each) of urediniospores suspension $\left(2.0 \mathrm{mg} \mathrm{ml}^{-1}\right)$ of the $H$. vastatrix, race II. The inoculations were done in three replicates, and occasionally, additional ones were used in the case of unclear symptom. The inoculated leaves were transferred to an acrylic box (gerbox), containing a $1.0 \mathrm{~cm}$ thick foam, saturated with distilled water and covered with nylon mesh. The gerbox were kept at the dark for $48 \mathrm{~h}$ at $22 \pm 2^{\circ} \mathrm{C}$, and then, exposed to a photoperiod of $12 \mathrm{~h}$ light, $12 \mathrm{~h}$ dark at $22^{\circ} \mathrm{C}$, at constant saturated humidity within the boxes. Symptoms were assessed 45 days after inoculation according to a 6-point scale of Tamayo et al. (1995), where 1-absence of symptoms; 2-small clorotic lesions; 3-median clorotic lesions, without spores formation; 4-clorotic lesions, with small urediniospores formation (urediniospores occupying $<25 \%$ of the lesion area); 5-sporulation occupying among 25 and 50\% of the lesion area; and 6-sporulation occupying $>50 \%$ of the lesion area. The plants were classified in two phenotyping groups, the ones scored 1-3 (absence of urediniospores) were considered resistant and 4-6 susceptible (presence of urediniospores).The phenotypic segregations of the populations were analyzed by the $\chi^{2}$ test, using the GENES software (Cruz 2006). $\chi^{2}$ tests were used to estimate probabilities for segregation ratios of the predicted and observed at $P<0.05$ probability.
DNA extraction

To identify AFLP markers linked to the resistant gene, two leaves from the parents and each $\mathrm{F}_{2}$ plant were collected, labeled and stored at $-80^{\circ} \mathrm{C}$ for later DNA extraction. The DNA was extracted with CTAB (Diniz et al. 2005). The DNA concentration was estimated by spectrophotometry (Smart SpecTM 3000). The integrity was evaluated on agarose gel $(1.0 \%)$ and visualized under UV light by ethidiumbromide-staining $\left(10 \mathrm{mg} \mathrm{ml}^{-1}\right)$ and photographed (Eagle-eye IITM Stratagene). Based on the estimated concentration, the DNA was diluted to $50 \mathrm{ng} \mu \mathrm{l}^{-1}$ and stored at $-20^{\circ} \mathrm{C}$.

\section{DNA reaction and amplification}

The AFLP analysis was performed according to the methodology described by Vos et al. (1995), with some modifications. In our study 176 primer combi-

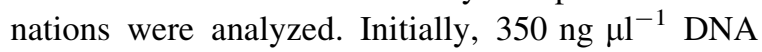
was digested, using a rare cutting (EcoRI) and a frequent cutting $(\mathrm{Mse}$ I) restriction enzyme. Adapters were ligated to the ends of the digested DNA fragments in a reaction containing T4 DNA ligase (Promega). The ligase reaction occurred at $20 \pm 2^{\circ} \mathrm{C}$ for $3 \mathrm{~h}$. Then the material was diluted 1:10 in TE $\mathrm{pH}$ 8.0 and stored at $-20^{\circ} \mathrm{C}$.

For the pre-selective amplification, the DNA fragments contained in the diluted solution of the ligase stage were amplified using primers complementary to adapters with one more selective nucleotide at the $3^{\prime}$ end. The reactions consisted of $1.50 \mathrm{ng} \mu \mathrm{l}^{-1}$ oligo EcoRI $+\mathrm{N}, 1.50 \mathrm{ng} \mu \mathrm{l}^{-1}$ oligo Mse I $+\mathrm{N}, 0.25 \mathrm{mM}$ of each dNTP (Promega), $1 \times$ Taq buffer, $1.5 \mathrm{mM} \mathrm{MgCl}_{2}, 2.5 \mu \mathrm{l}$ of ligase reaction diluted 1:10 and 2.5 units of Taq DNA polymerase (Phoneutria), amounting to a final volume of $25 \mu \mathrm{l}$. The amplification program consisted of 23 denaturation cycles at $94^{\circ} \mathrm{C}$ for $30 \mathrm{~s}$, annealing at $56^{\circ} \mathrm{C}$ for $60 \mathrm{~s}$ and an extension step at $72^{\circ} \mathrm{C}$ for $60 \mathrm{~s}$. In the end, the reaction product was diluted 1:40 in TE $\mathrm{pH}$ 8.0 and stored at $-20^{\circ} \mathrm{C}$.

In the selective amplification, primers were used containing three nucleotides added to the $3^{\prime}$ end. The reactions consisted of $1.25 \mathrm{ng} \mu \mathrm{l}^{-1}$ of $E c o \mathrm{RI}+\mathrm{NNN}$ primer, $1.50 \mathrm{ng} \mu \mathrm{l}^{-1}$ of $M s e \mathrm{I}+\mathrm{NNN}$ primer, $0.25 \mathrm{mM}$ of each dNTP (Promega), $1 \times$ Taq buffer, $1.5 \mathrm{mM} \mathrm{MgCl} 2,1.5$ units of Taq DNA polymerase 
(5 U. $\mu \mathrm{l}^{-1}$, Phoneutria) and $5.0 \mu$ l diluted pre-selective amplification reaction, amounting to a final reaction volume of $20 \mu \mathrm{l}$. The selective amplification program consisted of 13 cycles denaturation at $94^{\circ} \mathrm{C}$ for $30 \mathrm{~s}$, annealing at $65^{\circ} \mathrm{C}$ for $30 \mathrm{~s}\left(-0.7^{\circ} \mathrm{C}\right.$ at each cycle), extension at $72^{\circ} \mathrm{C}$ for $60 \mathrm{~s}$, followed by 23 cycles at $94^{\circ} \mathrm{C}$ for $30 \mathrm{~s}$, at $56^{\circ} \mathrm{C}$ for $30 \mathrm{~s}$ and at $72^{\circ} \mathrm{C}$ for $60 \mathrm{~s}$.

The amplified fragments were separated by electrophoresis in $6 \%$ polyacrylamide gel, at $80 \mathrm{~W}$, for approximately $3 \mathrm{~h}$. The gel was stained by the silver nitrate method (Creste et al. 2001), with some adjustments. After electrophoresis, the gel plate was immersed in a solution containing $10 \%$ absolute ethanol and $1 \%$ acetic acid under continuous slow stirring for $12 \mathrm{~min}$. Subsequently, the gel was washed with 21 ultrapure water under stirring for $1 \mathrm{~min}$. The pre-treatment was carried out by immersion in the gel solution containing $1.5 \%$ nitric acid for $3 \mathrm{~min}$. The gel was washed once more using 21 ultrapure water for 1 min under stirring. Subsequently, it was stained with $\mathrm{AgNO}_{3}$ solution $(0.3 \%$ ) for $25 \mathrm{~min}$, and washed twice (35 s each) with ultrapure water under stirring. Then the gel was immersed in $11 \mathrm{Na}_{2} \mathrm{CO}_{3}$ (3\%) and formaldehyde solution $(0.02 \%)$ and continuously stirred until the first bands appeared. The solution was discarded and another 11 of new solution added to the process. After immersion in 21 blocking solution (5\% acetic acid) for 5 min under slow agitation, the gel was washed in 21 ultrapure water for $1 \mathrm{~min}$.

Identification of the gene markers linked to resistance

The BSA (Bulk Segregant Analysis) technique (Michelmore et al. 1991), was used to identify AFLP markers linked to the resistance gene(s) present in Híbrido de Timor UFV 427-15. According to the authors, this methodology is a fast procedure to identify markers in specific genome regions. In our study, two contrasting bulked DNA sample were constructed, one containing DNA from five resistant $\mathrm{F}_{2}$ plants and the other containing DNA from five susceptible $\mathrm{F}_{2}$ plants.

\section{Statistical analysis}

The segregation of the heteromorphic fragments and resistance gene was evaluated by the $\chi^{2}$ test, using GENES software (Cruz 2006). The order of the markers and their distances to the coffee leaf rust resistance gene were determined using the recombination frequency calculation and GQMOL software (Cruz and Schuster 2001), expressed in centiMorgan (cM). It was considered $30 \%$ of the maximum recombination rate between the marker and the gene $\left(r_{\max }=0.3\right)$ and minimum LOD score of $3.0\left(\mathrm{LOD}_{\min }=3\right)$. The recombination percentage was obtained by the graphic procedure from maximum likelihood (Liu 1998). The algorithm used to define the best marker order was Rapid Chain Delineation-RCD (Doerge 1996).

\section{Results}

Disease resistance inheritance

The resistant parent Híbrido de Timor UFV 427-15 was completely free of any disease symptoms (score 1 in the disease evaluation) in all assessments and replications, while the susceptible parent Catuaí Amarelo UFV 2143-236 (IAC 30) was infected (usually score 6), as evidenced by the abundant sporulation.

Among the 160 plants examined in the $\mathrm{F}_{2}$ population, resistance was detected in 124 plants $(77 \%)$ while 36 were considered susceptible $(23 \%)$. These data indicated a segregation ratio of $3: 1$, as expected for a single dominant gene $\left(\chi^{2}=0.5336, P=0.4652\right.$; Table 1). The resistance/susceptibility segregation observed in $\mathrm{BCr}$ and $\mathrm{BCs}$ populations confirms the monogenic dominant inheritance of the Híbrido de Timor (Table 1).

Identification of AFLP markers associated with resistance gene

In this study, the AFLP technique proved to be suitable to identify molecular markers associated with coffee leaf rust resistance. A total of 176 AFLP primer combinations and about 11,000 bands were analyzed for ligation (Table 2). Depending on the primer combination used in the reaction, between 18 and 165 amplified DNA fragments were detected.

Of the combinations primers used, 57\% (101) were polymorphic between the two parents. These primers resulted in 278 clearly polymorphic fragments, present in Híbrido de Timor and absent in Catuaí. Only $5.75 \%$ (16) were also polymorphic between the two 
Table 1 Segregation analysis for resistance to H. vastatrix race II in populations derived from cross between the Híbrido de Timor UFV 427-15 and the Catuaí Amarelo UFV 2143-236 (IAC 30)

\begin{tabular}{|c|c|c|c|c|c|c|}
\hline \multirow[t]{2}{*}{ Population $^{\mathrm{a}}$} & \multicolumn{2}{|c|}{ No. of plants } & \multirow{2}{*}{$\begin{array}{l}\text { Observed ratio }^{\mathrm{b}} \\
\mathrm{R}: \mathrm{S}\end{array}$} & \multirow{2}{*}{$\begin{array}{l}\text { Expected ratio } \\
\text { R:S }\end{array}$} & \multirow[t]{2}{*}{$\chi^{2}$} & \multirow[t]{2}{*}{ Probability (\%) } \\
\hline & $\mathrm{R}$ & $\mathrm{S}$ & & & & \\
\hline UFV 427-15 & 20 & 0 & $1: 0$ & $1: 0$ & - & - \\
\hline UFV 2143-236 & 0 & 20 & $0: 1$ & $0: 1$ & - & - \\
\hline $\mathrm{F}_{1}$ & 20 & 0 & $1: 0$ & $1: 0$ & - & - \\
\hline $\mathrm{F}_{2}$ & 124 & 36 & $3.40: 1$ & $3: 1$ & 0.5336 & 46.5208 \\
\hline $\mathrm{BCs}$ & 63 & 72 & $0.87: 1$ & $1: 1$ & 0.3684 & 54.3866 \\
\hline $\mathrm{BCr}$ & 20 & 0 & 1:0 & 1:0 & - & - \\
\hline
\end{tabular}

${ }^{a}$ Population derived from a cross between the Híbrido de Timor UFV 427-15 and Catuaí Amarelo UFV 2143-236 (IAC 30)

b Observed and expected ratio for susceptible (S) and resistant (R)

Table 2 Number of AFLP primer combinations tested and polymorphisms observed among the resistant (Híbrido de Timor UFV 427-15) and the susceptible (Catuaí Amarelo UFV 2143-236) parent and DNA bulks

\begin{tabular}{ll}
\hline & $\begin{array}{l}E-\mathrm{CNN} / \\
M-\mathrm{TNN}\end{array}$ \\
\hline Total of AFLP primer combinations & 176 \\
Polymorphic primers between parents & 101 \\
Polymorphic bands present in UFV 427-15 & 278 \\
Polymorphic bands present in UFV 2143-236 & 142 \\
Polymorphic primers between parents and bulks & 09 \\
Polymorphic bands present in the resistant bulk & 16 \\
Polymorphic bands present in the susceptible bulk & 03 \\
\hline
\end{tabular}

a " $E$ " and " $M$ " designate the primers EcoRI and MseI, respectively, and " $\mathrm{N}$ " stands for each additional nucleotide in the primers

contrasting DNA bulks and three of them were present in all resistant individuals of the resistant bulk and absent in all susceptible ones. The candidate markers (E.CTC/M.TTT 405$)$, (E.CCT/M.TTC 230$)$ and (E.CGT/M.TGT ${ }_{300}$ ) correspond to DNA fragment of 405, 230 and $300 \mathrm{bp}$, respectively (Fig. 1).

The three candidate markers were confirmed to be linkage to the coffee leaf rust gene by screening 160 individuals of the segregating $F_{2}$ population. The segregation of the rust resistance gene and the three markers identified are shown in Table 3.

Co-segregation was observed between the resistance locus analyzed and the candidate markers (Table 3). The recombination analysis showed that marker E.CTC/M.TTT 405 is located at a distance of $8.69 \mathrm{cM}$ from the resistance gene, with a LOD score value of 18.91. Marker E.CCT/M.TTC 230 is located at a distance of $20.50 \mathrm{cM}$ from the gene, with a LOD score value of 6.15 and a third marker, E.CGT/ M.TGT $_{300}$, is located at $25.10 \mathrm{cM}$ with a LOD score value of 5.37 .

The map containing the coffee leaf rust resistance gene and the AFLP markers is shown in Fig. 2. Genetic mapping showed that the markers flanks both sides of the gene. These markers are linked, in the coupling phase, to the gene of coffee rust resistance.

\section{Discussion}

Disease resistance inheritance

The inheritance study of the Híbrido de Timor UFV427-15 to $H$. vastatrix race II, conducted in this study with three coffee populations $\left(\mathrm{F}_{2}, \mathrm{BCr}\right.$ and $\left.\mathrm{BCs}\right)$, confirmed that the resistance is monogenic and dominant. However, this result does not exclude the possibility that the loci under study correspond to a complex grouping of several resistance genes arranged in tandem and segregating as a single loci as reported for other species of plants (Richly et al. 2002; Town et al. 2006).

The accessions of Híbrido de Timor possess five known dominant genes, named $S_{H} 5, S_{H} 6, S_{H} 7, S_{H} 8$ and $S_{H} 9$ (Bettencourt et al. 1980, 1992). The resistance spectrum conferred by these genes can be totally or partially annulled by the combination of virulence genes $(v 5-v 9)$ present in different races of the fungus (Bettencourt and Rodrigues 1988; Pereira 1995). The race II of $H$. vastatrix used in this study 
Fig. 1 AFLP marker candidate of $405 \mathrm{bp}$ amplified by the primer combination E.CTC/M.TTT (a). A second (E.CCT/ M.TTC 230 ) amplified a fragment of $230 \mathrm{bp}$ (b) and a third (E.CGT/M.TGT (M00) ) amplified a fragment of 300 bp (c). From the left to the right the susceptible parent UFV 2143-236 and the resistant UFV 427-15. The arrows along the upper end of the gel indicate the five individuals of the susceptible bulk and the five individuals of the resistant bulk. The arrow on the left indicates the position of marker

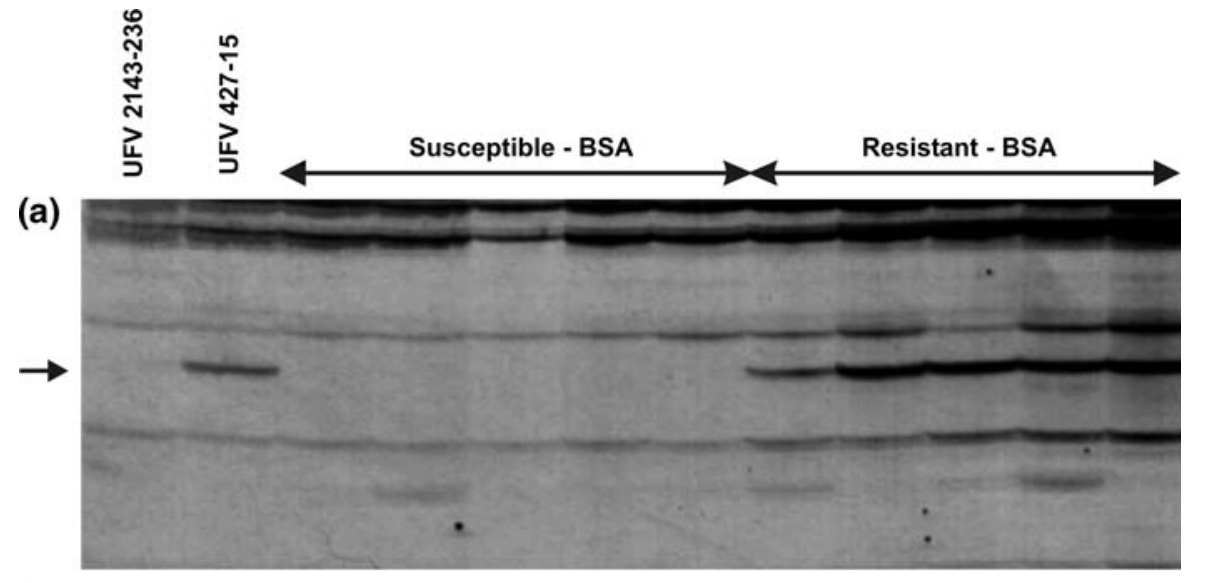

(b)
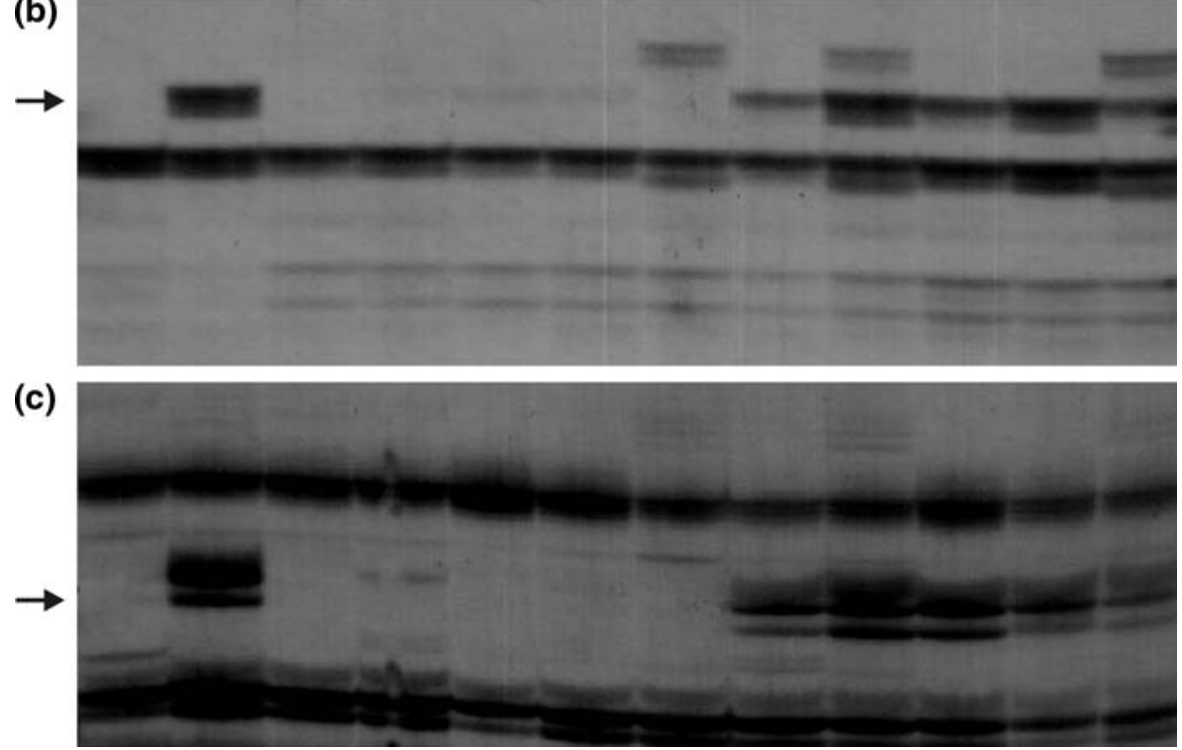

Table 3 Linkage analysis of the resistance gene and the three markers identified in the $F_{2}$ population from a cross between the Híbrido de Timor UFV 427-15 and Catuaí Amarelo UFV 2143-236

\begin{tabular}{|c|c|c|c|c|c|}
\hline Locus tested & Expected ratio & Observed ratio & $\chi^{2}$ & Probability (\%) & $\overline{\text { Distance }(\mathrm{cM})^{\mathrm{c}}}$ \\
\hline $\mathrm{R}$ & $3: 1^{\mathrm{a}}$ & $124: 36$ & 0.5336 & 46.5208 & - \\
\hline E.CTC/M.TTT 405 & $3: 1$ & $124: 36$ & 0.30 & 58.3882 & - \\
\hline E.CCT/M.TTC 230 & $3: 1$ & $133: 27$ & 5.6333 & 1.7622 & - \\
\hline E.CGT/M.TGT 300 & $3: 1$ & $118: 42$ & 0.1333 & 71.5000 & - \\
\hline R/E.CTC/M.TTT 405 & $9: 3: 3: 1^{b}$ & $118: 6: 6: 30$ & 85.1111 & 0.0000 & 8.69 \\
\hline R/E.CCT/M.TTC 230 & $9: 3: 3: 1$ & $118: 6: 15: 21$ & 47.5111 & 0.0000 & 20.50 \\
\hline R/E.CGT/M.TGT 300 & $9: 3: 3: 1$ & $103: 21: 15: 21$ & 24.1777 & 0.0022 & 25.10 \\
\hline
\end{tabular}

\footnotetext{
${ }^{a}$ Expected ratio for the monogenic and dominant inheritance in the $F_{2}$ population ( 3 resistant, $R_{-}$, or band presence : 1 susceptible, rr, or band absence)

${ }^{b}$ Expected ratio for segregation of two independent loci in the $\mathrm{F}_{2}$ progeny $\left(\mathrm{R} \_\right.$/+; $\mathrm{R} \_/-; \mathrm{rr} /+; \mathrm{rr} /-$ )

c Genetic distances in centiMorgans
} 


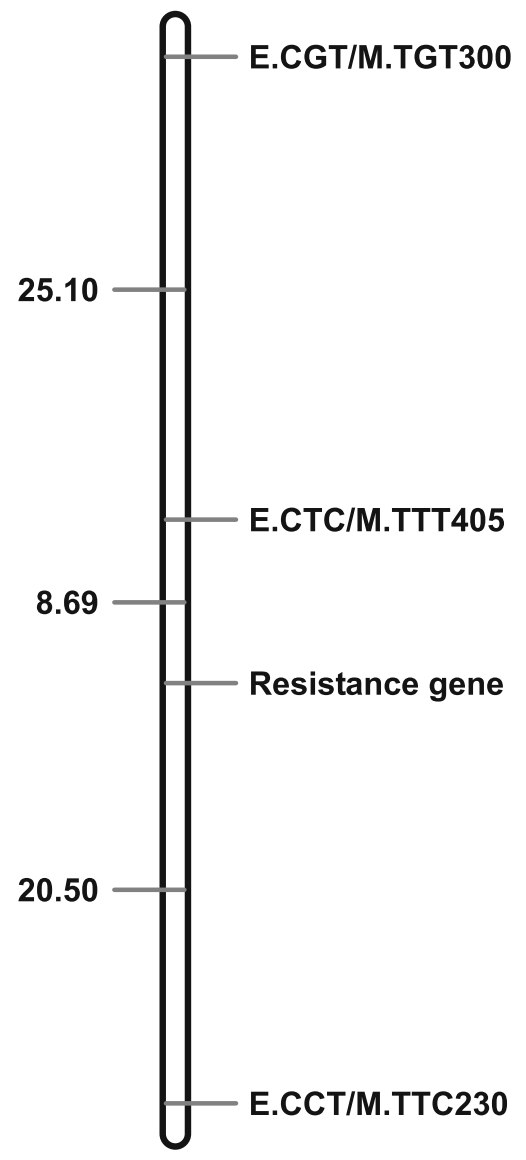

Fig. 2 Linkage map of the positions of the AFLP markers identified and the distances $(\mathrm{cM})$ between them and to the coffee leaf rust resistance gene

has only the virulence allele $v 5$, that is able to annul $S_{H} 5$ resistant gene (Bettencourt and Noronha-Wagner 1971). In this case, the resistance of the Híbrido de Timor UFV-427-15 to the race II must be conferred by another gene than $S_{H} 5$. Considering the fitting of the Coffea-Hemileia (Bettencourt and Rodrigues 1988) to the gene-for-gene model (Flor 1971), the resistance gene analyzed in this study differ also from $S_{H} 6$. This is support by previous study where was showed that the Híbrido de Timor UFV-427-15 is resistant to the race XXV (Pereira 1995), which has, in addition to $v 2$ and $v 5$, the virulence allele $v 6$ (Bettencourt and Rodrigues 1988). Therefore, the resistance gene identified in this study is most likely related to one of the genes $S_{H} 7, S_{H} 8$ or $S_{H} 9$ that were previously identified in Híbrido de Timor derivative (Bettencourt et al. 1980, 1992), or another unknown gene.
The analysis carried out with others accessions of Híbrido de Timor by our group revealed the presence of more than one gene in the resistance to $H$. vastatrix (Capucho et al. 2009). However, the finder of our study is particularly interesting for the development of a physical resistance mapping in order to do chromosomal landing and cloning of rust resistance gene in coffee. Furthermore, the existence of only one dominant gene, with a simple inheritance pattern, determining the resistance of coffee to $H$. vastatrix, would of course facilitate its transfer to susceptible cultivars.

Identification of AFLP markers associated with the resistance gene

The BSA methodology was efficient to identify the AFLP markers linked to the resistance gene to coffee leaf rust. In most studies using this method, the contrasting bulks are constructed with DNA of eight individuals (Ferreira et al. 2000; Caixeta et al. 2003; Lukens et al. 2006). According to Michelmore et al. (1991), the use of bulks with fewer plants can be results in false positives. In the contrary, in this study, the identification of linked markers was improved by the reduction to five individuals per bulk without increasing the number of false positives. Our results is in agreement with others obtained elsewhere (Muylle 2003; Muylle et al. 2005). The probability of a false positive in a $F_{2}$ population using dominant markers and five-plant bulks is $1.8 \times 10^{-6}$ and therefore virtually negligible (Muylle 2003).

The AFLP technique also proved to be efficient in the generation of markers linked to the rust resistance gene in coffee (Lashermes et al. 2000; Prakash et al. 2004). In our study, the two contrasting parents for rust resistance showed approximately 1.10 polymorphic AFLP bands per primer combination. These values are lower than those found by Lashermes et al. (2000), who compared accessions of C. arabica with genotypes derived from the Híbrido de Timor and found a rate of approximately 2.50 polymorphic AFLP bands amplified by a primer combination. This variation may be related to a lower genetic variability of the parents used in this study.

Three markers linked to the gene for rust resistance in the accession of Híbrido de Timor UFV 42715 were identified in the coupling phase, two of which flanking the resistance gene. The first marker 
(E.CTC/M.TTT ${ }_{405}$ ) is located at a distance of $8.69 \mathrm{cM}$, and the second (E.CCT/M.TTC 230 ) at $20.50 \mathrm{cM}$ from the resistance gene. The finding of markers flanking genes of interest could be useful for assisted breeding since the selection efficiency is greater when flanking markers are used, compared to the separate use (Corrêa et al. 2001). The increase of the efficiency can be attributed to the lower expected frequency of double recombinants in plants selected or discarded erroneously (Griffths et al. 1998).

The number of markers found here was significantly smaller than the one found by Prakash et al. (2004). These authors screened 80 AFLP primer combinations and identified 21 AFLP markers linked to the $\mathrm{SH}_{3}$ gene. We used a much larger number of primer combinations (176) and just three markers were found. This difference may be related to the lower genetic variability in the parents used in present study. The resistant parent Híbrido de Timor UFV 427-15 is a hybrid that originated from a cross between $C$. arabica and $C$. canephora underwent successive natural backcrossings with $C$. arabica, which makes it, in terms of genetic diversity, very similar to the susceptible parent Catuaí Amarelo UFV 2143-236. This successive backcrossings could be higher in this accession under study, since is one accession that have lost other resistance genes, and the lower rate of polymorphism linked to resistance gene found here could be linked to a smaller presence of C. canephora. On the other hand, the $\mathrm{F}_{2}$ population used by Prakash et al. (2004) was originated by the cross between C.arabica, and $C$. liberica, two genetically distant coffee species.

Considering the high genetic variability of the $H$. vastatrix and the time consumed to have accurately disease evaluation in the field, coffee breeders would benefit from the ability to select for resistance to leaf rust using genetic markers, which is still not a reality in Brazilian coffee breeding. Implementation of a marker assisted selection strategy in coffee would dramatically increase the efficiency of breeding programs (Lashermes et al. 1997; Van der Vossen 2005).

In conclusion, this is the first report on molecular markers flanking the rust resistance gene in Híbrido de Timor. The information is the basic step in the construction of a denser genetic map, and will helpful to find closer markers to be converted into SCAR (Sequence Characterized Amplified Regions), for direct use in marker assisted coffee breeding for rust resistance in Brazil. A new population recently generated by our group using these parents, confirmed the linkage of these three markers to the resistance gene, allowing the identification of new markers a little closer to the resistance gene. Genetic mapping are under progress to make these markers useful to develop a physical map to clone this resistance gene in near future.

\section{References}

Bettencourt AJ, Noronha-Wagner M (1971) Genetic factors conditioning resistance of Coffea arabica L. to Hemileia vastatrix Berk Et Br. Agron Lusit 31:285-292

Bettencourt AJ, Rodrigues CJ (1988) Principles and practice of coffee breeding for resistance to rust and other diseases. In: Clarke RJ, Macrae R (eds) Coffee: agronomy. Elsevier Applied Science 3, London, pp 199-234

Bettencourt AJ, Noronha-Wagner M, Lopes M (1980) Fator genético que condiciona a resistência do clone 1343/269 (Híbrido de Timor) à Hemileia vastatrix Berk \& Br. Brot Genet 76:53-58

Bettencourt AJ, Lopes J, Palma S (1992) Factores genéticos que condicionam a resistência às raças de Hemileia vastatrix Berk. et Br. dos clones-tipo dos grupos 1, 2 e 3 de derivados de Híbrido de Timor. Brot Genet XIII(LXXX): 185-194

Caixeta ET, Borém A, Azevedo SF, Nietsche S, Barros EG, Moreira MA (2003) Inheritance of angular leaf spot resistance in common bean line BAT 332 and identification of RAPD markers linked to the resistance gene. Euphytica 3:297-303. doi:10.1023/B:EUPH.0000004948. 41083.1f

Capucho AS, Caixeta ET, Maciel-Zambolim E, Zambolim L (2009) Herança da resistência do Híbrido de Timor UFV443-03 à ferrugem do cafeeiro. Pesquisa Agropecuária Brasileira 44:276-282. doi:10.1590/S0100-204X200 9000300009

Corrêa RX, Good-God PIV, Oliveira MLP, Nietsche S, Moreira M, Barros EG (2001) Herança da resistência à mancha-angular do feijoeiro e identificação de marcadores moleculares flanqueando o loco de resistência. Fitopatol Bras 26:27-32

Creste S, Tulmann-neto A, Figueira A (2001) Detection of single sequence repeat polymorphisms in denaturing polyacrylamide sequencing gels by silver staining. Plant Mol Biol Rep 19(4):299-306

Cruz CD (2006) Genes versão 2006.4.1: programa GENES versão Windows. Editora UFV, Viçosa, Brazil

Cruz CD, Schuster I (2001) GQMOL: programa para análise de genética quantitativa molecular. Desenvolvido pelo setor de Genética da Universidade Federal de Viçosa, Viçosa, Brasil

Diniz LEC, Sakiyama NS, Lashermes P, Caixeta ET, Oliveira ACB, Zambolim EM, Loureiro ME, Pereira AA, Zambolim L (2005) Analysis of AFLP marker associated to 
the Mex-1 resistance locus in Icatu progenies. Crop Breed Appl Biotechnol 5:387-393

Doerge RW (1996) Constructing genetic maps by rapid chain delineation. JQTL 2:121-132

Fazuoli LC, Medina Filho HP, Gonçalves W, Guerreiro Filho O, Silvarolla MB (2002) Melhoramento do cafeeiro: variedades tipo arabica obtidas no Instituto Agronômico em Campinas. In: Zambolim L (ed) O estado da arte de tecnologias na produção de café. UFV, Viçosa, Brasil, pp 63-215

Fazuoli LC, Oliveira ACB, Toma-Braguini M, Silvarolla MB (2005) Identification and use of sources of durable resistance to coffee leaf rust at the IAC. In: Zambolim L et al (eds) Durable resistance to coffee leaf rust. UFV, Viçosa, Brasil, pp 137-185

Ferreira CF, Borém A, Carvalho GA, Nietsche S, Paula TJ, Barros EG, Moreira MA (2000) Inheritance of angular leaf spot resistance in Common Bean and identification of a RAPD marker linked to a resistance gene. Crop Sci 40:1130-1133

Flor HH (1971) Current status of the gene-for-gene concept. Annu Rev Phytopathol 9:275-296

Griffths AJF, Miller JH, Suzuki DT, Lewontin RC, Gelbart WM (1998) Introdução à genética. Trad. Paulo Armando

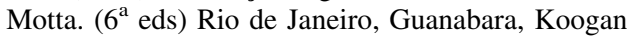

Kushalappa AC, Eskes AB (1989) Advances in coffee rust research. Annu Rev Phytopathol 27:503-531

Lashermes P, Agwnada CO, Anthony F, Combes MC, Trouslot P, Charrier A (1997) Molecular marker-assisted selection: a powerful approach for coffee improvement. In: Proceedings of the 13th international conference on coffee science (ASIC), Nairobi, pp 474-480

Lashermes P, Andrzejewski S, Bertrand B, Combes MC, Dussert S, Graziosi G, Trouslot P (2000) Molecular analysis of introgressive breeding in coffee (Coffea Arabica L.). Theor Appl Genet 100:139-146

Liu BH (1998) Statistical genomics: linkage, mapping, and QTL analysis. CRC Press, Boca Raton, USA, 605 pp

Lukens LN, Pires JC, Leon E, Vogelzang R, Oslach L, Osborn $\mathrm{T}$ (2006) Patterns of sequence loss and cytosine methylation within a population of newly resynthesized Brassica napus allopolyploids. Plant Physiol 140:336-348

Matiello JB, Santinato R, Garcia AWR, Almeida SR, Fernandez DR (2002) Cultura de café no Brasil. In: Matiello JB (ed) Novo Manual de Recomendações. MAPA/PROCAFE, Rio de Janeiro

Michelmore RW, Paran I, Kesseli RV (1991) Identification of markers linked to disease-resistance genes by bulked segregant analysis: a rapid method to detect markers in specific genomic regions by using segregating populations. Proc Natl Acad Sci 88:9828-9832

Muylle, H. (2003) Genetic analysis of crown rust resistance in ryegrasses (Lolium spp.) using molecular markers. Dissertation, Universiteit Gent, Gent

Muylle H, Baert J, Bockstaele EV, Pertijs J, Rolda-Ruiz I (2005) Four QTLs determine crown rust (Puccinia coronata f. sp. lolii) resistance in a perennial ryegrass (Lolium perenne) population. Heredity 95:348-357

Pereira AA (1995) Herança da resistência a Hemileia vastatrix Berk, et Br. em cafeeiros derivados do Híbrido de Timor. Dissertation, Universidade Federal de Viçosa, Viçosa
Pereira AA, Moura WM, Zambolim L, Sakiyama NS, Chaves GM (2002) Melhoramento genético do cafeeiro no Estado de Minas Gerais: cultivares lançados e em fase de obtenção. In: Zambolim L (ed) O estado da arte de tecnologias na produção de café. UFV, Viçosa, Brasil, pp 253-295

Prakash NS, Marques DV, Varzea VMP, Silva MC, Combes MC, Lashermes P (2004) Introgression molecular analysis of a leaf rust resistance gene from Coffea liberica into Coffea arabica L. Theor Appl Genet 109:1311-1317

Prakash NS, Ganesh D, Bhat SS (2005) Population dynamics of coffee leaf rust (Hemileia vastatrix BERK. ET BR.) and recent advances in rust research in India. In: Zambolim L et al (eds) Durable resistance to coffee leaf rust. UFV, Viçosa, Brasil, pp 411-442

Richly E, Kurth J, Leister D (2002) Mode of amplification and reorganization of resistance genes during recent Arabidopsis thaliana evolution. Mol Biol Evol 19:76-84

Sera T, Alteia MZ, Petek MR (2002) Melhoramento do cafeeiro: variedades melhoradas no Instituto Agronômico do Paraná (IAPAR). In: Zambolim L (ed) O estado da arte de tecnologias na produção de café. UFV, Viçosa, Brasil, pp 217-251

Srinivasan KH, Narasimhaswamy RL (1975) A review of coffee breeding work done at the Government coffee experiment station, Balehonnur. Indian Coffee 34:311321

Tamayo PJ, Vale FXR, Zambolim L, Chaves GM, Pereira AA (1995) Catimor resistance to coffee leaf rust and virulence of physiological races of Hemileia vastatrix. Fitopatol Bras 20:572-576

Town CD, Cheung F, Maiti R, Crabtree J, Haas BJ, Wortman JR, Hine EE, Althoff R, Arbogast TS, Tallon LJ, Vigouroux M, Trick M, Bancroft I (2006) Comparative Genomics of Brassica oleracea and Arabidopsis thaliana reveal gene loss, fragmentation, and dispersal after polyploidy. Plant Cell 18:1348-1359

Van der Vossen HAM (2001) Coffee breeding practices. In: Clarke RJ, Vitzthum OG (eds) Coffee recent developments: agronomy, vol 1. Blackwell, London, pp 184-201

Van der Vossen HAM (2005) State-of-the-art of developing durable resistance to biotrophic pathogens in crop plants, such as coffee leaf rust. In: Zambolim L et al (eds) Durable resistance to coffee leaf rust. UFV, Viçosa, Brasil, pp 1-30

Várzea VMP, Marques DV (2005) Population variability of Hemileia vastatrix vs. coffee durable resistance. In: Zambolim L et al (eds) Durable resistance to coffee leaf rust. UFV, Vicosa, Brasil, pp 53-74

Vishveshwara S (1974) Periodicity of Hemileia in arabica selection-S 795. Indian Coffee 38:49-51

Vos P, Hogers R, Bleeker M, Reijans M, van de Lee T, Hornes M, Frijters A, Pot J, Peleman J, Kuiper M (1995) AFLP: a new technique for DNA fingerprinting. Nucleic Acids Res 23:4407-4414

Wagner M, Bettencourt AJ (1965) Inheritance of reaction to Hemileia vastatrix Berk. Et Br. In: Wagner M, Bettencourt AJ (eds) Coffea arabica L. Progress report. Coffee Rust Research Center, Oeiras, Portugal, pp 1960-1965

Zambolim L, Vale FXR, Pereira AA, Chaves GM (1999) Manejo integrado das doenças do cafeeiro. In: Zambolim 
L (ed) Produção de café com qualidade. UFV, Viçosa, Brasil, pp 134-215

Zambolim L, Vale FXR, Costa H, Chaves GM (2002) Epidemiologia e controle integrado da ferrugem do cafeeiro.
In: Zambolim L (ed) O estado da arte de tecnologias na produção de café. UFV, Viçosa, Brasil, pp 369-450 